\title{
Seed Germination in Oil Palm (Elaeis guineensis Jacq.): A Review of Metabolic Pathways and Control Mechanisms
}

\author{
Jing Cui ${ }^{1}$, Emmanuelle Lamade ${ }^{2,3}$ and Guillaume Tcherkez ${ }^{1,4, *(D)}$ \\ 1 Research School of Biology, ANU Joint College of Science, Australian National University, Canberra, \\ 2601 ACT, Australia; jing.cui@anu.edu.au \\ 2 CIRAD, UPR Systèmes de Pérennes, 34398 Montpellier, France; emmanuelle.lamade@cirad.fr \\ 3 Systèmes de Pérennes, Université de Montpellier, CIRAD, 34398 Montpellier, France \\ 4 Institut de Recherche en Horticulture et Semences (IRHS), Université d'Angers, INRAE Angers, \\ 42 rue Georges Morel, 49782 Beaucouzé cedex, France \\ * Correspondence: guillaume.tcherkez@anu.edu.au
}

Received: 1 June 2020; Accepted: 12 June 2020; Published: 13 June 2020

\begin{abstract}
Oil palm is an oil-producing crop of major importance at the global scale. Oil palm mesocarp lipids are used for myriads industrial applications, and market demand has been growing for decades. In addition, oil palm seeds are oleaginous, and the oil extracted therefrom can be used for several purposes, from food to cosmetics. As such, there is a huge need in oil palm seeds to maintain the global cohort of more than 2 billion trees. However, oil palm seed germination is a rather difficult process, not only to break dormancy, but also because it is long and often reaches lower-than-expected germination rates. Surprisingly, despite the crucial importance of germination for oil palm plantation management, our knowledge is still rather limited, in particular about germinating oil palm seed metabolism. The present review incorporates different pieces of information that have been obtained in the past few years, in oil palm and in other palm species, in order to provide an overview of germination metabolism and its control. Further insights can also be gained from other oleaginous model plants, such as Arabidopsis or canola, however, palm seeds have peculiarities that must be accounted for, to gain a better understanding of germinating seed metabolism.
\end{abstract}

Keywords: oil palm; seed; lipid remobilization; germination; metabolism; haustorium

\section{Introduction}

Oil palm (Elaeis guineensis Jacq.) is presently the most productive oil crop, with a total global cultivation area of 19 million ha, and a recorded production of 0.27 gigatons of fruits and 71.4 megatons of palm oil [1]. This huge cultivated surface area represents about 2.7 billion trees. On average, oil palm fields are generally renewed every $25 \mathrm{y}$, thus having an average replanting turn-over of $4 \% \mathrm{y}^{-1}$ [2], meaning that each year, about 100 million trees have to be replaced. In addition to the increase in cultivated surface area in the past decades, this generates a huge demand in oil palm sapling cultivation in nurseries and, of course, in seedling production from seed germination or in vitro cloning (Figure 1) (for a review on oil palm seed distribution and management, see [3]). Developing new crosses or hybrids (e.g., E. guineensis $x$ oleifera) associated with better resistance to diseases (such as fatal yellowing) also requires growing palms from seeds. However, seed germination is still a hurdle in oil palm cultivation-as in many palm species-because of the relatively short seed storage time (preferably less than 16 weeks), methods required to break dormancy, and long germination and seedling establishment time, up to 9 months in nursery and up to several years in nature. 


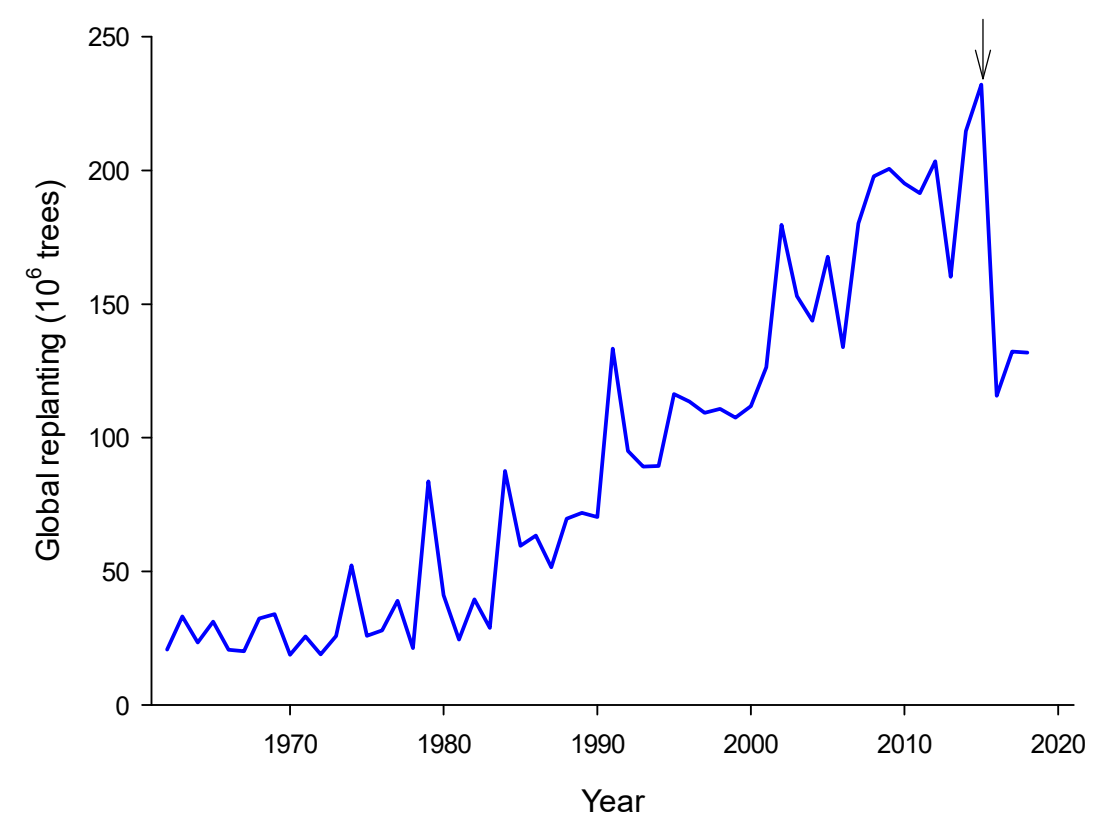

Figure 1. Estimated global demand in oil palm seedlings for new plantations and turn-over of old plantations. Computed from total world oil palm cultivation surface area using an average density of 143 trees ha ${ }^{-1}$ (FAO 2018). The arrow shows the year 2015 where total cultivated area reached a maximum.

Surprisingly, despite these difficulties to germinate and the high demand at the global scale, the physiology of oil palm germination and seedling establishment is not very well known. Most metabolic studies were carried out in the 1980s [4-7] and, since then, there has been very little progress in our knowledge of molecular actors and metabolic regulations involved in germination stricto sensu, seed storage remobilization and seedling development of oil palm. This species produces oily (oleaginous) seeds encapsulated into a hard endocarp layer, forming a kernel (photographs in Figure 2). As such, oil palm seeds are also used as a source of oil (palmist oil), with industrial applications that differ from mesocarp oil. The prevalence of lipids in kernels also implies specific metabolic pathways of remobilization, that is, lipid degradation and conversion to sugars. In this brief review, we will summarize metabolic aspects of oil palm seed germination (lato sensu) using recent data obtained not only in oil palm but also in other closely related palm species of the same botanical tribe (Cocoeae). The importance of primary metabolism in defining seed quality has been summarized recently [8]. We thus take advantage of the present review to emphasize metabolic aspects that are currently unknown and deserve further research, in particular, to find new avenues to optimize oil palm seed germination. 


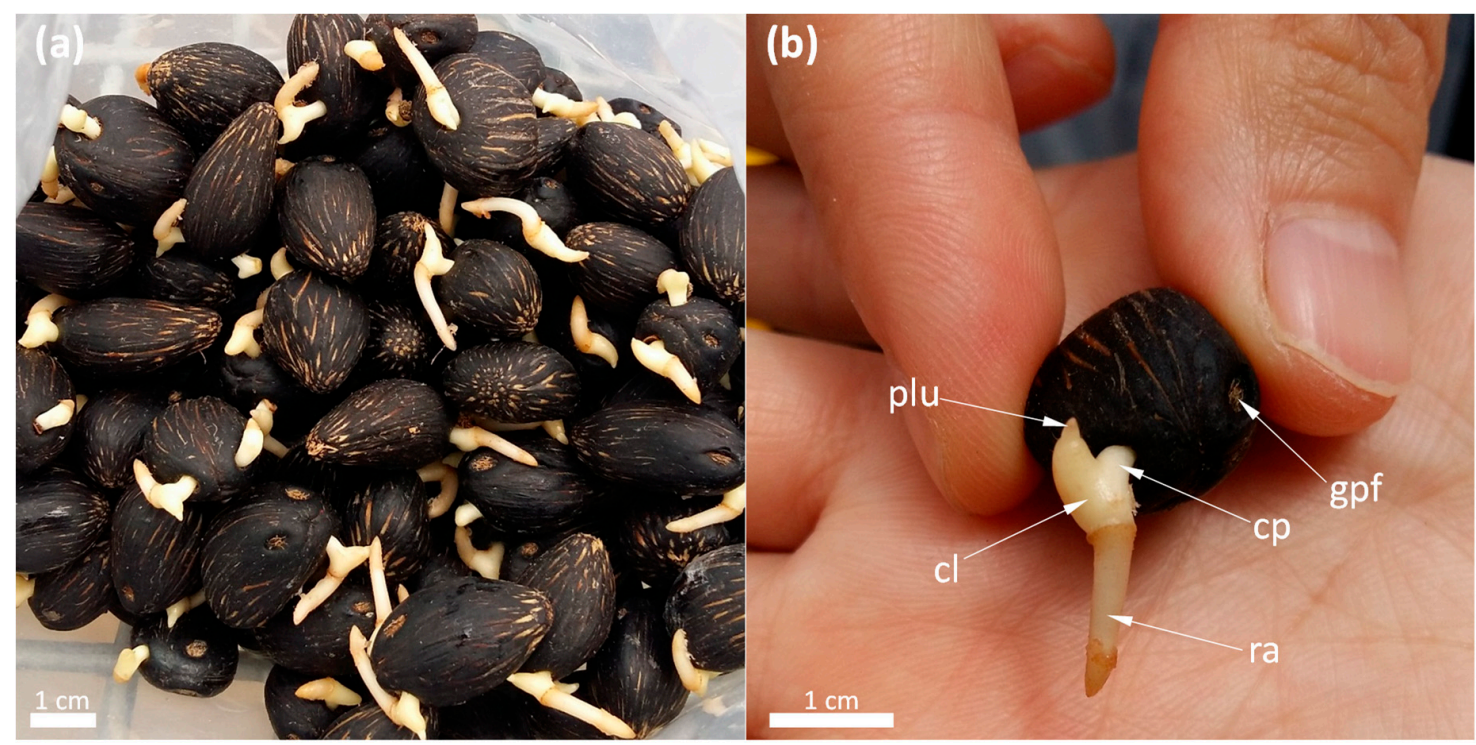

Figure 2. Photographs of germinated oil palm seeds: overview of seeds as they are in nurseries upon delivery, in polyethylene bag (a); anatomy of a germinated seed (b), showing one the germinative pore (gpf), the cotyledonary petiole (cp), cotyledonary ligule (cl), the radicle (ra) and the plumule (plu). Photographed seeds are at stage IV (see Figure 3 for the definition of stages). Photographs: (C) the author (Jing Cui).

\section{Setting the Scene: Specific Germination Stages}

By definition, germination is the process by which seeds break their quiescent life, imbibe and start development so that the radicle pierces seed envelopes (integuments and endocarp). In palm tree species, such as oil palm, this definition has to be modified, to take into account the fact that the first anatomical structure that pierces seed envelopes is not the radicle, but a specific structure that represents the cotyledonary petiole. In other words, radicle development (as well as plumule development) are part of post-germinative events. The cotyledonary petiole is associated with (and attached to) the cotyledon (equivalent to the scutellum in grasses), which here forms a haustorium (Figure 2; Figure 3). The haustorium has a critical metabolic role since it interfaces the endosperm, which contains reserves that are digested and remobilized to sustain seedling development. That is, the haustorium plays multiple roles [4,9,10]: (i) induces enzymatic activities in the endosperm to allow remobilization; (ii) synthesizes digestion enzymes; (iii) transfers metabolites from the digestion zone to the seedling; (iv) involves specific metabolic pathways to coordinate post-germination events. The haustorium increases in size up to c. 90 days and its metabolic degradation starts at about 160 days [11]. Histological and metabolic steps in germination stricto sensu and post-germination have been recently described precisely in macaw palm (Acrocomia aculeata) [9], which may serve as a model species for palm seed germination. There, seven developmental stages have been recognized (described in Figure 3). Germination stricto sensu represents stages I-II, while stages III-VI are post-germinative. Importantly, these stages are associated with differences in prevalent metabolic activities. In fact, lipids are not the first seed reserves to be remobilized. Endosperm proteins appear to be broken down first, rapidly followed by carbohydrates [9,12]. Interestingly, reserves remobilization seems to start very early in palm seeds (at stage I) and, thus, is part of germination stricto sensu, whereas in most species (such as Arabidopsis or canola, two other oleaginous seeds), it starts in stage III, and is thus a post-germinative phenomenon. 


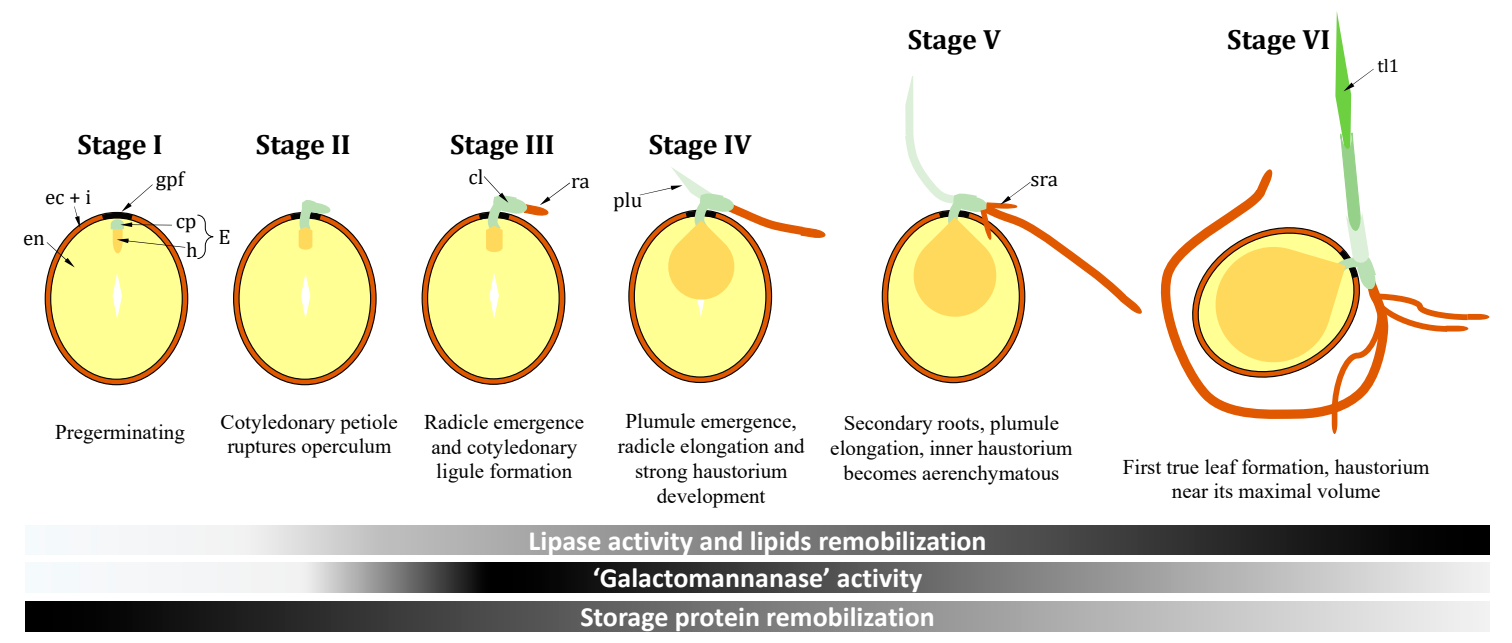

Figure 3. Simplified overview of oil palm seed germination. Germination is spelt out into six steps, following palm seeds germination description in stages I to VI proposed by Mazzotini-dos-Santos et al. (2016). The overall seed structure is simplified here and only shows endocarp and integuments $(e c+i)$, endosperm (en), the germinative fibrous pore (or operculum; gpf) and the embryo made of the haustorium primordium (h) and the cotyledonary petiole (cp). The haustorium and the cotyledonary petiole form the embryo (E). Once the cotyledonary petiole pierces the operculum, the radicles (ra) emerges and a cotyledonary ligule forms (cl). Then, the shoot primordium (plumule; plu) emerges, secondary roots develop (sra) and eventually, the shoot produces successive leaves including the first true leaf forming a photosynthetic blade (t11). This figure uses the term "galactomannanase" to encapsulate all enzymatic activities (such as $\beta$-endomannanases) involved in galactomannanes remobilization.

\section{Non-lipid Reserve Remobilization}

Non-germinated oil palm seeds contain (in \% dry weight) c. 53\% lipids, $38 \%$ insoluble carbohydrates and fibers, $8 \%$ proteins, $3 \%$ inorganic salts and $1 \%$ starch and soluble sugars $[11,13,14]$. Reserve proteins (which have been better characterized in embryos than in endosperm) are mostly made of globulins and albumins [15-19]. It is believed that the endosperm itself produces proteases to catalyze reserve protein hydrolysis, which are activated by a yet unknown signal coming from the haustorium [9]. It is possible that a hormone (such as a gibberellin) is involved but this is presently uncertain (see below the section Control of Germination). In other species with oleaginous seeds, such as Arabidopsis, proteins can also be directed to hydrolysis via the proteasome (summarized in [20]). Presumably, amino acids produced therefrom can easily penetrate into the haustorium via transporters (currently not characterized in oil palm). It is worth noting that reserve proteins in oil palm seeds have a high proportion of N-rich amino acids such as glutamine (20-30\%) but quite interestingly, also arginine (10-20\%) [16]. Arginine is not only a source of nitrogen (arginine cleavage by arginase yields urea which can be broken down to ammonium by urease, and ammonium can in turn be refixed by glutamine synthetase), but also a precursor of polyamines (putrescine, spermidine, spermine) and thus $\beta$-alanine (Figure 4 ). 


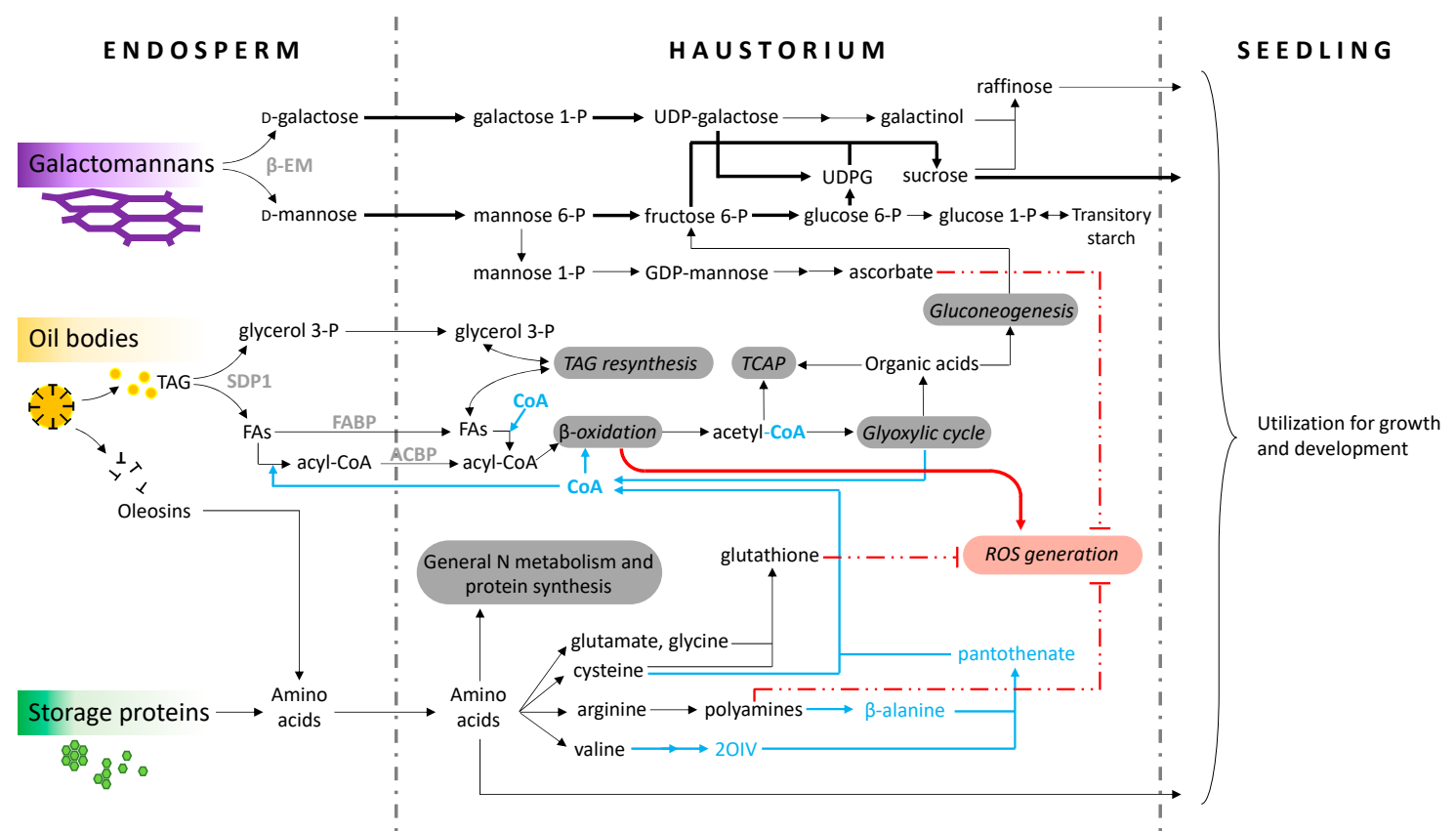

Figure 4. Overview of metabolic pathways involved in oil palm seed germination showing the role of the haustorium. For clarity, this figure does not show all intermediates, transporters and possible metabolic routes, and does not recall time windows for reserve utilization (shown in Figure 3). Enzymes discussed in text are in bold grey. Reactive oxygen species (ROS) generation and mitigation is shown in red. Coenzyme A cycle and synthesis are shown in light blue. Sucrose synthesis from galactomannanes degradation is shown in thick black arrows. Abbreviations: 2OIV, 2-oxoisovalerate; ACBP, acyl-CoA binding proteins; $\beta E M, \beta$-endomannanases; FABP, fatty acid binding proteins; FAs, fatty acids; ROS, Reactive oxygen species; TAG, triacylglycerols; TCAP, tricarboxylic acid pathway; UDPG, UDP-glucose. Here, oil bodies are shown as comprising oleosins (see further discussion in main text).

Oil palm seed reserve carbohydrates are mostly in the form of insoluble (galacto) mannanes, which have been shown by ${ }^{13} \mathrm{C}-\mathrm{NMR}$ spectroscopy to be mostly made of linear mannans with a small proportion (less than $20 \%$ ) of galactomannans [21]. These polymers are accumulated in cell walls and thus their degradation may participate in endosperm cellular thinning to favor cotyledonary petiole emergence, as suggested in macaw palm [10]. Galactomannans hydrolysis (via $\beta$-endomannanase activity) has been shown in situ by histochemistry endosperm, but not in the haustorium in macaw palm [9], suggesting that $\beta$-endomannanases are neither produced nor secreted by the haustorium epidermis, but are synthesized by the endosperm itself. Cell wall carbohydrate degradation probably also involves-like in other crops [22] - some other enzymatic activities, such as galacturonases, glucanases, cellulases, expansins, etc., in particular to facilitate the cotyledonary petiole emergence. In fact, in palm species other than oil palm, the degradation of pectins in the micropylar region (beneath the germination pore, Figure 3) has been demonstrated [10].

Although this has not been shown directly (typically using ${ }^{13} \mathrm{C}$ or ${ }^{14} \mathrm{C}$ isotope tracing), it is likely that sugar residues produced by (galacto)mannans hydrolysis (mannose, galactose) are not consumed by haustorium catabolism to a high extent, since $\beta$-endomannanase hydrolytic activity peaks at stage III [9], while lipid remobilization has already started. That is, haustorium catabolism mostly utilizes products of lipid degradation. At this stage, it is worth mentioning that in principle, mannose 6-phosphate may be used to synthesize ascorbate via GDP-mannose [23], and galactose may not only form UDP-glucose (thereby sustaining sucrose synthesis), but also galactinol for raffinose synthesis, which is also involved in sugar transport (Figure 4). Galactinol and raffinose have indeed been shown to be part of oil palm metabolome in all organs [24]. 


\section{Lipid Remobilization}

Kernel lipids are mostly made of triacylglycerols (TAG), while other compounds are minor constituents (such as $\alpha$-tocopherol, phospholipids or carotenoids). Kernel oil (palmist oil) is richer in saturated fatty acids than mesocarp oil (about $89 \%$ fatty acids are saturated); also, medium chain fatty acids prevail, in particular lauric acid (C12:0) and myristic acid (C14:0), which account for up to 55 and $18 \%$ of total kernel fatty acids [25]. This seed lipid composition has been shown to be representative of many tropical palms growing in areas where the average temperature is high enough to avoid undesirable phase transition to solid fat [26]. Oil palm mesocarp oil bodies are believed to be devoid of oleosins [27], however, the oil palm genome contains nine oleosin-like proteins, suggesting that unlike mesocarp lipids, kernel oil bodies might comprise oleosins. Future proteomics analyses of pure kernel oil bodies are warranted to provide further insight on this aspect.

In macaw palm, both the endosperm and the haustorium synthesize a lipase that cleaves esterified fatty acids of oil bodies [9]. Surprisingly, enzymatic assays carried out with oil palm endosperm and haustorium samples have been unsuccessful to show lipase activity, in contrast to seedling tissues [7]. As shown in other species, such as Arabidopsis [28,29] the lipase that cleaves TAG is certainly of the Sugar Dependent 1 (SDP1) family, and in fact, the oil palm genome encodes for two SDP1-like lipases (scaffolds p5.00-sc00032-p0085 and p5.00-sc00086-p0021 in [30]). The failure to retrieve lipase activity in haustorium and endosperm samples could have come from the fact that a physical association with proteins and, perhaps, peroxisomes is necessary [29]. Alternatively, lipid remobilization could also involve autophagy, as recently suggested for other seed systems [20]. In any case, free fatty acids liberated by TAG hydrolysis must then be transferred to the haustorium, where enzymes of $\beta$-oxidation are located [5,7]. In other words, fatty acids generated by lipid cleavage must go through several membranes (two plasma membranes (endosperm and haustorium cells) and then the peroxisome membrane). This transport is certainly in the form of coenzyme A (CoA) esters produced by both endosperm and haustorium fatty acid-coenzyme A synthetase [5]. Transport into the peroxisome certainly involves an $\mathrm{ABC}$ family transporter homologous to the $\mathrm{ABC}$ transporter COMATOSE (CTS; oil palm has five CTS with a protein sequence identity of $c$. $75 \%$ compared to Arabidopsis CTS) [31], as well as acyl-CoA binding proteins (ACBP) and fatty acid binding proteins (FABP) [32]. Both ACBP and FABP are represented in oil palm genome (where there is actually only one annotated FABP, encoded by p5.00-sc00100-p0042, and six ACBP). Lipid quantification and tracing experiments with ${ }^{14} \mathrm{C}$-labelled laurin (trilauroylglycerol) or free fatty acids have clearly established that the haustorium does not only accumulate free fatty acids, but also resynthesizes lipids from imported fatty acids, such as TAG, diacylglycerols and monoacylglycerols, but also polar lipids, including with longer-chain and unsaturated fatty acids $[6,11,33]$.

Fatty acids CoA esters are directed to peroxisomal degradation via $\beta$-oxidation and gluconeogenesis, and key enzyme activities (such as isocitrate lyase, malate synthase and phosphoenolpyruvate carboxykinase) have indeed been found to be specific to haustorium tissue $[4,7]$. Like TAG synthesis in kernel [34], the degradation of fatty acid CoA esters in haustorium is specific to medium chain fatty acids $\left(\mathrm{C}_{10}-\mathrm{C}_{12}\right)$, longer chain fatty acids being much less efficiently (three to four times less) degraded [6]. Sugars generated by lipid remobilization and gluconeogenesis (in addition to galactomannanes hydrolysis, see above) are transiently converted to starch at stage III in the haustorium of Butia, macaw, coconut and oil palms $[9,11,35,36]$. Still, sucrose is the major product synthesized by the haustorium and exported to the developing seedling. In fact, sucrose has been found to represent up to $14 \%$ of haustorium dry weight in oil palm [11] and 5\% of haustorium fresh weight in coconut palm [36].

Lipid remobilization is associated with a high requirement in CoA, since fatty acids must be esterified to CoA for metabolization. In oleaginous seeds such as canola, the CoA content increases during seed development, but declines during maturation (reviewed in [37]). Although fatty acid CoA esters are eventually cleaved and thus CoA metabolism forms a cycle (Figure 4), CoA biosynthesis is essential for lipid degradation (transport and $\beta$-oxidation) to maintain pools of intermediates and 
proceed at full capacity. Furthermore, in the haustorium, $0.5 \%$ only of fatty acids are present in their free form [33], suggesting that conjugation and transport as CoA esters is fast. Therefore, the de novo synthesis of $\mathrm{CoA}$ is an important metabolic event during germination. In Arabidopsis, there is a strong increase in the content of mRNA encoding for pantothenate kinase (enzyme of the CoA biosynthetic pathway) during imbibition [38]. In oil palm, the degradation of proteins, which precedes the onset of lipid remobilization is likely essential to allow CoA biosynthesis from amino acids. This includes arginine metabolism leading to $\beta$-alanine (see Non-lipid Reserves Remobilization), which is a critical intermediate in the biosynthesis of CoA. Parenthetically, it is worth noting that in plants, $\beta$-alanine comes from spermine oxidation in the peroxisome via polyamine oxidase [37], producing $\mathrm{H}_{2} \mathrm{O}_{2}$ and, thus, contributing to oxidative stress (further addressed below).

Here, two important aspects are poorly, if at all, documented: (i) The regulation of CoA content also likely involves CoA degradation, which takes place in both peroxisomes and mitochondria in Mammals [39]. However, pathways and molecular actors of CoA degradation are virtually unknown in plants. (ii) Since fatty acids are transported as CoA esters, it implies that free CoA likely cycles back from the haustorium to the endosperm, once the esters have been broken down. This process can potentially take place in two ways, either via CoA transporters or CoA degradation to pantothenate that would then be transported. To our knowledge, known CoA transporters are limited to a potato mitochondrial transporter [40] and the Arabidopsis NAD peroxisomal transporter PNX, which can also transport CoA as well as dephospho-CoA [41]. Further research on this aspect is clearly needed to clarify how CoA homeostasis is achieved in germinating oil palm seeds and, in particular, to understand how CoA is compartmentalized between tissues (haustorium, endosperm).

\section{ROS Metabolism}

During oleaginous seed germination, there is a considerable generation of reactive oxygen species (ROS) by fatty acid oxidation. The synthesis of enzymes involved in mitigating oxidative stress has been demonstrated with proteomics in germinating Arabidopsis seeds [42]. In fact, acyl-CoA oxidation utilizes $\mathrm{O}_{2}$ either via FAD as a cofactor (via FAD-dependent acyl-CoA dehydrogenases) or directly (with acyl-CoA oxidases), thereby generating $\mathrm{H}_{2} \mathrm{O}_{2}$ which is then scavenged by peroxisomal catalase [31]. At this stage, it is important to remember that one $\mathrm{H}_{2} \mathrm{O}_{2}$ molecule is produced for each acetyl-CoA generated by $\beta$-oxidation, meaning that ROS production by $\beta$-oxidation is substantial. An increase in $\mathrm{H}_{2} \mathrm{O}_{2}$ concentration has indeed been found in endosperm and haustorium of germinating Butia palm seeds [35] and, after imbibition, superoxide dismutase and glutathione reductase activities increase, followed by catalase, thereby down-regulating oxidative stress [43]. Mitochondria are also a likely source of ROS in the first steps of germination. In seeds other than oil palm (maize, Arabidopsis), there are considerable changes in mitochondria shape and fusion-fission dynamics just after imbibition, with a large tubuloreticular shape comprising less cristae and a high sensitivity to $\operatorname{KCN}[44,45]$. This suggests there is a low capacity of both alternative oxidase and ATP synthase, which might in turn favor mitochondrial ROS generation. Polyamines, which have also been found to facilitate oil palm embryogenesis in vitro [46], may play a role in the mitigation of mitochondrial ROS generation (reviewed in [47]).

More generally, oxidative stress down-regulation involves the key metabolites ascorbate, glutathione and $\alpha$-tocopherol. Presumably, in the case of oil palm, the relatively high amount of S-containing amino acids in reserve proteins [18] must be beneficial to glutathione synthesis, while galactomannans remobilization is a potential source of ascorbate (Figure 4). $\alpha$-tocopherol is also synthesized de novo during germination, as shown in dwarf palm (Chamaerops humilis); in addition, in this species, $\alpha$-tocopherol synthesis appears to be stimulated by $\mathrm{H}_{2} \mathrm{O}_{2}$, jasmonic acid (JA) and gibberellins [48]. $\alpha$-tocopherol is essential to quench, not only ROS, but also lipid peroxidation triggered by lipoxygenase, which is, in turn, the source of JA [49]. In macaw palm, ROS are also generated during artificial seed ageing under wet heat which favors lipid peroxidation [50]. As such, $\alpha$-tocopherol is probably an important actor to down-regulate lipid peroxidation at the very first steps of palm seed 
germination, just after imbibition. In fact, across different palm species, just after imbibition, there is a peak in $\mathrm{H}_{2} \mathrm{O}_{2}$ that seems to coincide with that in JA and $\alpha$-tocopherol content $[35,51,52]$.

\section{Control of Germination}

The means to improve germination rates have been a hot topic of oil palm biology for decades. Oil palm seeds have a mixed physical-physiological dormancy, which is often found in Monocots forming an embryo with a low degree of development in mature seeds $[53,54]$. In practice, it means that there is: (i) a physical barrier for embryonic structures to pierce the micropylar endosperm region; and (ii) a physiological barrier, governed by hormonal signals that need to be removed to allow germination. Importantly, the physical and physiological barriers do interact. That is, methods that tend to alleviate the physical barrier have an effect on hormones and metabolites, thereby favoring physiological dormancy breaking. Many methods have been tried to promote seed germination, such as wet heat, chemicals (such as cyanamide) or dry heat, but dry heat $\left(39^{\circ} \mathrm{C}\right.$ for up to 10 weeks, seeds being contained in a polyethylene bag) is by far the most utilized method including in hybrids E. guineensis $x$ oleifera [55-57]. Optimal duration and temperature have been investigated and seem to depend on the genetic material (oil palm progeny) used [58,59]. Temperature fluctuations after the induction period under dry heat have also been reported to further promote germination [60]. Interestingly, the mechanisms by which dry heat induces germination are still not totally clear. It is possible that it triggers germination via (i) oxidative stress-this would agree with the promoting effect on germination of both $\mathrm{H}_{2} \mathrm{O}_{2}$ [12,59] and high oxygen atmosphere, depending on temperature [61]. In fact, the heat treatment has been found to cause a decrease in catalase activity and an increase in glucose 6-phosphate dehydrogenase activity [62]; and (ii) a change in the balance between abscissic acid and gibberellins. The latter hypothesis may explain why the gibberellin $\mathrm{GA}_{3}$ is often added during seed treatment to further increase the germination rate, although with a rather variable success, due to the fact that $\mathrm{GA}_{3}$ needs to penetrate the seed, and this seems to require the mechanical piercing of the germinative pore $[63,64]$. Similarly, in macaw palm, the physical inhibition of germination coming from the resistance exerted by the germinative pore is not influenced by $\mathrm{GA}_{3}$ but $\mathrm{GA}_{3}$ stimulates germination by favoring embryo growth and reconfiguring cell walls of micropylar endosperm $[10,51]$. Additionally, in oil palm, the heat treatment has been found to decrease the force required by the embryo to pierce the germinative pore [62].

However, $\mathrm{GA}_{3}$ is probably not the essential factor in the natural process of germination in oil palm. Hormonal profiling of germinating oil palm seeds has shown that several hormones vary in the first days, not only gibberellins, which only show a small increase [65]. The most visible events are a strong decrease in abscissic acid and a modest increase in auxin [52,66]. The decrease in abscissic acid (and its antagonism with gibberellins) is not surprising, since it is an essential component of dormancy breaking in mixed physical-physiological dormant seeds [53,67]. In Arabidopsis germination, the antagonism between gibberellins and abscissic acid relies on a complicated interaction network [68], and has been shown to involve the COP9 signalosome, which mediates the regulation of protein degradation via the proteasome [69].

Ethylene synthesis stimulators (hydrogen cyanamide or ethephon) have also been used to stimulate oil palm germination [70], suggesting that ethylene (and/or oxidative stress, which is another consequence of hydrogen cyanamide treatment) might be involved in dormancy breaking. In macaw palm, there is more than a two-fold decrease in ACC (ethylene precursor) upon imbibition, also suggesting that ACC consumption and therefore ethylene synthesis may accompany germination induction [51]. The increase in cytokinins is visible much later (after several weeks), and is probably related to the regulation of tissue proliferation in stages III-VI $[52,66]$. Parenthetically, the involvement of hormones in seed germination is quite different to that in the transition of somatic embryos development in vitro. In fact, in vitro somatic embryos generated from fast-growing callus are generally cultured with anti-auxins and cytokinins and then morphogenesis is induced by $\mathrm{GA}_{3}$ and NAA (naphthalene acetic acid) [71]. This means that the hormone cocktail required for artificial oil palm seeds (somatic 
embryos embedded into a gel-based milieu) is very different from the natural hormone profile during seed germination.

Hormones also regulate germination and dormancy-breaking via the control of metabolism. In non-oleaginous seeds such as Sichuan pepper tree (which produces starchy seeds), gibberellins inhibitSDP1-dependent lipid remobilization and increase sugar content [72]. In Astragalus (proteaginous legume seed), abscissic acid and methyl-JA delay lipid remobilization [65]. In oleaginous seeds, it is also probable that gibberellins and abscissic acid regulate lipid remobilization. For example, a WRKY transcription factor that acts as negative regulator of abscissic acid signaling is crucial to up-regulate lipid remobilization during germination in sunflower [73]. A comprehensive analysis of WRKY factors in oil palm has been provided [74], and future research will likely provide more insight on differential expression during the germination of WRKY factors associated with abscissic acid and gibberellin signaling. Additionally, mitochondrial reactivation during seed imbibition has been shown to be stimulated by gibberellins and inhibited by abscissic acid in Arabidopsis [45]. Still, specific mechanisms involving hormones in the control of metabolism in oil palm germination remain to be elucidated. Additionally, the potential interaction with nutrients is not very well documented. During kernel maturation, there is a strong decrease in the content of several elements such as $\mathrm{Cu}, \mathrm{Mn}, \mathrm{Mg}$ and $\mathrm{K}$ [75]. Therefore, when germination starts, there could be a transient deficiency and, consequently, it is likely that a medium enriched in such elements (or alternatively, a hormonal milieu that favors nutrient absorption) may facilitate germination. Although kernel phosphorus $(\mathrm{P})$ content has also been found to decline during maturation [75], transcriptomics analyses have shown that kernel maturation is associated with the expression of genes encoding phytate synthesis [76]. This indicates that germination implies the remobilization of phytate to liberate free phosphate and sustain metabolism (such as glycolysis and ATP synthesis). In fact, in distantly related palms (Phoenix and Washingtonia), acidic phosphatase (AP) activity has been found in the endosperm and the haustorium [77]. However, the molecular mechanisms involved in AP activation are presently unknown.

\section{Perspectives}

In this brief review, we have outlined the most important events occurring in oil palm metabolism during germination. Although key metabolic pathways (such as $\beta$-oxidation) are common to all oleaginous seeds including oil palm and model plants like Arabidopsis, palm seeds have peculiarities, such as the involvement of the haustorium that digests the endosperm and eventually invades the seed. This is associated with metabolic imperatives such as fatty acid transport and coenzyme A cycling. Despite the importance of these aspects, advances in germination metabolism have been very limited in oil palm since the 1980 s, where labelling with ${ }^{14} \mathrm{C}$ has shown the interfacing role of the haustorium. It is probable that future studies will focus on functional genomics of oil palm germination. Typically, metabolomics will have to be used to resolve the spatial and temporal profile of metabolites in the different tissues of the germinating seed (as recently done in maize, [78]). Similarly, proteomics analyses will be of importance to find key transporters, confirm the localization of enzymes involved in reserve remobilization (not only lipids), and identify proteins associated with kernel oil bodies. This knowledge will in turn be useful to determine molecular traits associated with better seed germination performance and thus to help oil palm breeding.

Funding: G.T. thanks the financial support of the Région Pays de la Loire and Angers Loire Métropole via the research grant Connect Talent Isoseed. J. C. was supported by an Australia Awards PhD Scholarship.

Conflicts of Interest: The authors declare no conflict of interest. The funders had no role in the design of the study; in the collection, analyses, or interpretation of data; in the writing of the manuscript, or in the decision to publish the results.

\section{References}

1. FAO Database FAOSTAT. Available online: http://www.fao.org/faostat/en/\#data. (accessed on 25 May 2020).

2. Corley, R.H.V.; Tinker, P.B. The Oil Palm; Wiley Blackwell: Chichester, UK, 2016. 
3. Durand-Gasselin, T.; Cochard, B. Oil palm seed distribution. Oilseeds Fats Crops Lipids 2005, 12, $148-153$. [CrossRef]

4. Alang, Z.C.; Moir, G.F.J.; Jones, L.H. Composition, degradation and utilization of endosperm during germination in the oil palm (Elaeis guineensis Jacq.). Ann. Bot. 1988, 61, 261-268. [CrossRef]

5. Oo, K.C. Biochemistry of the germinated oil palm seedlings. PORIM Bull. 1986, 12, 36-41.

6. Oo, K.C. Stumpf, P.K. The metabolism of the germinating oil palm (Elaeis guineensis) seedlings. Plant Physiol. 1983, 73, 1033-1037. [CrossRef] [PubMed]

7. Oo, K.C.; Stumpf, P.K. Some enzymic activities in the germinating oil palm (Elaeis guineensis) seedling. Plant Physiol. 1983, 73, 1028-1032. [CrossRef]

8. Domergue, J.B.; Abadie, C.; Limami, A.; Way, D.; Tcherkez, G. Seed quality and carbon primary metabolism. Plant Cell Environ. 2019, 42, 2776-2788. [CrossRef]

9. Mazzottini-dos-Santos, H.C.; Ribeiro, L.M.; Oliveira, D.M.T. Roles of the haustorium and endosperm during the development of seedlings of Acrocomia aculeata (Arecaceae): Dynamics of reserve mobilization and accumulation. Protoplasma 2016, 254, 1563-1578. [CrossRef]

10. Mazzottini-dos-Santos, H.C.; Ribeiro, L.M.; Oliveira, D.M.T. Structural changes in the micropylar region and overcoming dormancy in Cerrado palms seeds. Trees 2018, 32, 1415-1428. [CrossRef]

11. Boatman, S.G.; Crombie, M. Fat metabolism in the West African oil palm (Elaeis guineensis). J. Exp. Bot. 1958, 9, 52-74. [CrossRef]

12. Bicalho, E.M.; Motoike, S.Y.; Lima e Borges, E.E.d.; Ataíde, G.d.M.; Guimarães, V.M. Enzyme activity and reserve mobilization during Macaw palm (Acrocomia aculeata) seed germination. Acta Botanica Brasilica 2016, 30, 438-444. [CrossRef]

13. Alimon, A. The nutritive value of palm kernel cake for animal feed. Palm Oil Dev 2004, 40, 12-14.

14. Akpanabiatu, M.I.; Ekpa, O.D.; Mauro, A.; Rizzo, R. Nutrient composition of Nigerian palm kernel from the dura and tenera varieties of the oil palm (Elaeis guineensis). Food Chem. 2001, 72, 173-177. [CrossRef]

15. Fournié, F. Etude de la maturation des embryons de palmier à huile (Elaeis guineensis Jacq.): Protéines de réserve et facteurs intervenant dans la tolérance à la dessication. Master's Thesis, Université des sciences et techniques du Languedoc, Montpellier, France, 1994.

16. Morcillo, F.; Aberlenc-Bertossi, F.; Trouslot, P.; Hamon, S.; Duval, Y. Characterization of 2S and 7S storage proteins in embryos of oil palm. Plant Sci. 1997, 122, 141-151. [CrossRef]

17. Aberlenc-Bertossi, F.; Chabrillange, N.; Duval, Y.; Tregear, J. Contrasting globulin and cysteine proteinase gene expression patterns reveal fundamental developmental differences between zygotic and somatic embryos of oil palm. Tree Physiol. 2008, 28, 1157-1167. [CrossRef] [PubMed]

18. Chang, S.K.; Ismail, A.; Yanagita, T.; Esa, N.M.; Baharuldin, M.T.H. Biochemical characterisation of the soluble proteins, protein isolates and hydrolysates from oil palm (Elaeis guineensis) kernel. Food Biosci. 2014, 7, 1-10. [CrossRef]

19. Cha, T.S.; Habib Shah, F. Kernel-specific cDNA clones encoding three different isoforms of seed storage protein glutelin from oil palm Elaeis guineensis. Plant Sci. 2001, 160, 913-923. [CrossRef]

20. Masclaux-Daubresse, C.; d'Andrea, S.; Bouchez, I.; Cacas, J.-L. Reserve lipids and plant autophagy. J. Exp. Bot. 2020. In press. [CrossRef]

21. Daud, M.J.; Jarvis, M.C. Mannan of oil palm kernel. Phytochemistry 1992, 31, 463-464. [CrossRef]

22. Nonogaki, H.; Chen, F.; Bradford, K.J. Mechanisms and genes involved in germination sensu stricto; Annual Plant Reviews Online; Wiley: London, UK, 2018; pp. 264-304.

23. Smith, A.G.; Croft, M.T.; Moulin, M.; Webb, M.E. Plants need their vitamins too. Curr. Opin. Plant Biol. 2007, 10, 266-275. [CrossRef]

24. Cui, J.; Davanture, M.; Zivy, M.; Lamade, E.; Tcherkez, G. Metabolic responses to potassium availability and waterlogging reshape respiration and carbon use efficiency in oil palm. New Phytologist 2019, 223, 310-322. [CrossRef]

25. Tan, C.-P.; Nehdi, I.A. The physicochemical properties of palm oil and its components. In Palm Oil: Production, Characterization and Uses; Lai, O.-M., Tan, C.-P., Akoh, C.C., Eds.; AOCS Press: Berlin, Germany, 2012; pp. 377-391.

26. Guerin, C.; Serret, J.; Montúfar, R.; Vaissayre, V.; Bastos-Siqueira, A.; Durand-Gasselin, T.; Tregear, J.; Morcillo, F.; Dussert, S. Palm seed and fruit lipid composition: Phylogenetic and ecological perspectives. Ann. Bot. 2020, 125, 157-172. [CrossRef] [PubMed] 
27. Hsieh, K.; Huang, A.H.C. Endoplasmic reticulum, oleosins, and oils in seeds and tapetum cells. Plant Physiol. 2004, 136, 3427-3434. [CrossRef] [PubMed]

28. Theodoulou, F.L.; Eastmond, P.J. Seed storage oil catabolism: A story of give and take. Curr. Opin. Plant Biol. 2012, 15, 322-328. [CrossRef] [PubMed]

29. Cui, S.; Hayashi, Y.; Otomo, M.; Mano, S.; Oikawa, K.; Hayashi, M.; Nishimura, M. Sucrose production mediated by lipid metabolism suppresses the physical interaction of peroxisomes and oil bodies during germination of Arabidopsis thaliana. J. Biol. Chem. 2016, 291, 19734-19745. [CrossRef] [PubMed]

30. Nik Shazana, N.; Rosli, R.; Ab Halim, M.; Chan, K.; Nagappan, J.; Azizi, N.; Amiruddin, N.; Tatarimova, T.; Low, E. PalmXplore: Oil palm gene database. Database 2018, 1, 9.

31. Baker, A.; Graham, I.A.; Holdsworth, M.; Smith, S.M.; Theodoulou, F.L. Chewing the fat: $\beta$-oxidation in signalling and development. Trends Plant Sci. 2006, 11, 124-132. [CrossRef]

32. Hooks, M.A. Molecular biology, enzymology, and physiology of $\beta$-oxidation. In Plant Peroxisomes: Biochemistry, Cell Biology and Biotechnological Applications; Baker, A., Graham, I.A., Eds.; Springer: Dordrecht, The Netherland, 2002; pp. 19-55.

33. Opute, F.I. Lipid composition and the role of the haustorium in the young seedling of the West African oil palm, Elaeis guineensis Jacq. Ann. Bot. 1975, 39, 1057-1061. [CrossRef]

34. Sun, C.; Cao, Y.-z.; Huang, A.H.C. Acyl coenzyme A preference of the glycerol phosphate pathway in the microsomes from the maturing seeds of palm, maize, and rapeseed. Plant Physiol. 1988, 88, 56-60. [CrossRef]

35. Souza Dias, D.; Monteiro Ribeiro, L.; Sérgio Nascimento Lopes, P.; Aclécio Melo, G.; Müller, M.; Munné-Bosch, S. Haustorium-endosperm relationships and the integration between developmental pathways during reserve mobilization in Butia capitata (Arecaceae) seeds. Ann. Bot. 2018, 122, 267-277. [CrossRef]

36. Sugimura, Y.; Murakami, T. Structure and function of the haustorium in germinating coconut palm seed. J.A.R.Q. 1990, 24, 1-14.

37. Webb, M.E.; Smith, A.G. Pantothenate biosynthesis in higher plants. Adv. Bot. Res. 2011, 58, $203-255$.

38. Nakabayashi, K.; Okamoto, M.; Koshiba, T.; Kamiya, Y.; Nambara, E. Genome-wide profiling of stored mRNA in Arabidopsis thaliana seed germination: Epigenetic and genetic regulation of transcription in seed. Plant J. 2005, 41, 697-709. [CrossRef] [PubMed]

39. Kerr, E.W.; Shumar, S.A.; Leonardi, R. Nudt8 is a novel CoA diphosphohydrolase that resides in the mitochondria. FEBS Lett. 2019, 593, 1133-1143. [CrossRef] [PubMed]

40. Neuburger, M.; Day, D.A.; Douce, R. Transport of coenzyme A in plant mitochondria. Arch. Biochem. Biophys. 1984, 229, 253-258. [CrossRef]

41. Agrimi, G.; Russo, A.; Pierri, C.L.; Palmieri, F. The peroxisomal NAD+ carrier of Arabidopsis thaliana transports coenzyme A and its derivatives. J. Bioenerg. Biomembr. 2012, 44, 333-340. [CrossRef]

42. Galland, M.; Huguet, R.; Arc, E.; Cueff, G.; Job, D.; Rajjou, L. Dynamic Proteomics Emphasizes the Importance of Selective mRNA Translation and Protein Turnover during Arabidopsis Seed Germination. Mol. Cell. Proteomics 2014, 13, 252-268. [CrossRef]

43. Bicalho, E.M.; Santos, T.R.S.d.; Garcia, Q.S. Abscisic acid and the antioxidant system are involved in germination of Butia capitata seeds. Acta Botanica Brasilica 2019, 33, 174-178. [CrossRef]

44. Logan, D.C.; Millar, A.H.; Sweetlove, L.J.; Hill, S.A.; Leaver, C.J. Mitochondrial biogenesis during germination in maize embryos. Plant Physiol. 2001, 125, 662-672. [CrossRef]

45. Paszkiewicz, G.; Gualberto, J.M.; Benamar, A.; Macherel, D.; Logan, D.C. Arabidopsis seed mitochondria are bioenergetically active immediately upon imbibition and specialize via biogenesis in preparation for autotrophic growth. Plant Cell 2017, 29, 109-128. [CrossRef]

46. Rajesh, M.K.; Radha, E.; Karun, A.; Parthasarathy, V.A. Plant regeneration from embryo-derived callus of oil palm - the effect of exogenous polyamines. Plant Cell, Tissue Organ Cult. 2003, 75, 41-47. [CrossRef]

47. Cui, J.; Pottosin, I.; Lamade, E.; Tcherkez, G. What is the role of putrescine accumulated under potassium deficiency? Plant, Cell Environ. 2020. In press. [CrossRef] [PubMed]

48. Siles, L.; Alegre, L.; González-Solís, A.; Cahoon, E.B.; Munné-Bosch, S. Transcriptional regulation of vitamin E biosynthesis during germination of dwarf fan palm seeds. Plant, Cell Physiol. 2018, 59, 2490-2501. [CrossRef] [PubMed]

49. Munné-Bosch, S.; Alegre, L. The function of tocopherols and tocotrienols in plants. Crit. Rev. Plant Sci. 2002, 21, 31-57. [CrossRef] 
50. Barreto, L.C.; Garcia, Q.S. Accelerated ageing and subsequent imbibition affect seed viability and the efficiency of antioxidant system in macaw palm seeds. Acta Physiologiae Plantarum 2017, 39, 72. [CrossRef]

51. Bicalho, E.M.; Pintó-Marijuan, M.; Morales, M.; Müller, M.; Munné-Bosch, S.; Garcia, Q.S. Control of macaw palm seed germination by the gibberellin/abscisic acid balance. Plant Biol. 2015, 17, 990-996. [CrossRef]

52. Wang, Y.; Htwe, Y.M.; Li, J.; Shi, P.; Zhang, D.; Zhao, Z.; Ihase, L.O. Integrative omics analysis on phytohormones involved in oil palm seed germination. BMC Plant Biol. 2019, 19, 363. [CrossRef]

53. Finch-Savage, W.E.; Leubner-Metzger, G. Seed dormancy and the control of germination. New Phytol. 2006, 171, 501-523. [CrossRef]

54. Baskin, J.M.; Baskin, C.C. What kind of seed dormancy might palms have? Seed Sci. Res. 2013, $24,17-22$. [CrossRef]

55. Lima, W.A.A.; Lopes, R.; Green, M.; Cunha, R.N.V.; Abreu, S.C.; Cysne, A.Q. Heat treatment and germination of seeds of interspecific hybrid between American oil palm (Elaeis oleifera (H.B.K) Cortes) and African oil palm (Elaeis guineensis Jacq.). J. Seed Sci. 2014, 36, 451-457. [CrossRef]

56. Comont, G.; Jacquemard, J.C. Germination of oil palm seeds (E. guineensis) in polyethylene bags "dry heat" method. Oléagineux 1977, 32, 149-154.

57. Corrado, E.; Wuidart, W. Germination of oil palm (E. guineensis) seeds in polyethylene bags. The dry heat method. Oléagineux 1990, 45, 511-518.

58. Fondom, N.; Etta, C.; Mih, A. Breaking seed dormancy: Revisiting heat-treatment duration on germination and subsequent seedling growth of oil palm (Elaeis guineensis Jacq.) progenies. J. Agric. Sci. 2010, 2, 101-110. [CrossRef]

59. Beugré-Manéhonon, M.; Kouakou-Kouakou, L.; Bognonkpé, J.P.; Konan, K.; Kouakou-Tanoh, H.; Kouadio-Yatty, J. Effect of storage and heat treatments on the germination of oil palm (Elaeis guineensis Jacq.) seed. African J. Agric. Res. 2009, 4, 931-937.

60. Norsazwan, M.; Sinniah, U.R.; Puteh, A.; Namasivayam, P.; Mohaimi, M.; Aminuddin, I.A. Temperature fluctuation improves oil palm (Elaeis guineensis) Dura x Pisifera seed germination. Seed Sci. Technol. 2020, 48, 49-55. [CrossRef]

61. Hussey, G. An analysis of the factors controlling the germination of the seed of the oil palm, Elaeis guineensis (Jacq.). Ann. Bot. 1958, 22, 259-284. [CrossRef]

62. Alang, Z.C. Some physiological effects of the commercial heat treatment of oil palm (Elaeis guineensis) seeds. In Proceedings of the International Conference on Oil Palm in Agriculture in the Eighties. Session-Physiology and Propagation, Kuala Lumpur, Malaysia, 17-20 June 1981; pp. 17-20.

63. Kaewtaphan, P.; Chanprasert, W.; Sayasoonthorn, S.; Wongsri, O.; Petchrrun, T. Germination of de-operculated oil palm (Elaeis guineensis) seed as affected by gibberellic acid (GA 3$)$. Seed Sci. Technol. 2016, 44, $298-309$. [CrossRef]

64. Norsazwan, M.; Puteh, A.; Rafii, M.Y. Oil palm (Elaeis guineensis) seed dormancy type and germination pattern. Seed Sci. Technol. 2016, 44, 1-12.

65. Yang, N.; Guo, X.; Wu, Y.; Hu, X.; Ma, Y.; Zhang, Y.; Wang, H.; Tang, Z. The inhibited seed germination by ABA and MeJA is associated with the disturbance of reserve utilizations in Astragalus membranaceus. J. Plant Interact. 2018, 13, 388-397. [CrossRef]

66. Jiménez, V.M.; Guevara, E.; Herrera, J.; Alizaga, R.; Bangerth, F. Changes in hormone concentrations during dormancy release of oil palm (Elaeis guineensis) seeds. Seed Sci. Technol. 2008, 36, 575-587. [CrossRef]

67. Yan, A.; Chen, Z. The pivotal role of abscisic acid signaling during transition from seed maturation to germination. Plant Cell Rep. 2017, 36, 689-703. [CrossRef]

68. Holdsworth, M.J.; Bentsink, L.; Soppe, W.J.J. Molecular networks regulating Arabidopsis seed maturation, after-ripening, dormancy and germination. New Phytologist 2008, 179, 33-54. [CrossRef] [PubMed]

69. Jin, D.; Wu, M.; Li, B.; Bücker, B.; Keil, P.; Zhang, S.; Li, J.; Kang, D.; Liu, J.; Dong, J.; et al. The COP9 Signalosome regulates seed germination by facilitating protein degradation of RGL2 and ABI5. PLOS Genetics 2018, 14, e1007237. [CrossRef] [PubMed]

70. Herrera, J.; Alizaga, R.; Guevara, E. Use of chemical treatments to induce seed germination in oil palm (Elaeis guineensis Jacq.). ASD Oil Palm Papers 1998, 18, 1-16.

71. Duval, Y.; Durand-Gasselin, T.; Konan, K.; Pannetier, C. Multiplication végétative du palmier à huile par culture in vitro. Stratégies et résultats. Oléagineux 1988, 43, 39-44. 
72. Sun, J.; Jia, H.; Wang, P.; Zhou, T.; Wu, Y.; Liu, Z. Exogenous gibberellin weakens lipid breakdown by increasing soluble sugars levels in early germination of Zanthoxylum seeds. Plant Sci. 2019, 280, 155-163. [CrossRef]

73. Raineri, J.; Hartman, M.D.; Chan, R.L.; Iglesias, A.A.; Ribichich, K.F. A sunflower WRKY transcription factor stimulates the mobilization of seed-stored reserves during germination and post-germination growth. Plant Cell Rep. 2016, 35, 1875-1890. [CrossRef]

74. Xiao, Y.; Zhou, L.; Lei, X.; Cao, H.; Wang, Y.; Dou, Y.; Tang, W.; Xia, W. Genome-wide identification of WRKY genes and their expression profiles under different abiotic stresses in Elaeis guineensis. PLoS ONE 2017. [CrossRef]

75. Kok, S.-Y.; Namasivayam, P.; Ee, G.C.-L.; Ong-Abdullah, M. Biochemical characterisation during seed development of oil palm (Elaeis guineensis). J. Plant. Res. 2013, 126, 539-547. [CrossRef]

76. Xu, L.; Yuan, Y.; Zhang, L.; Wan, L.; Zheng, Y.; Zhou, P.; Li, D. Identification and characterization of differential gene expression in the mesocarp and kernel of oil palm nuts using suppression subtractive hybridization. Tree Genet. Genomes 2011, 7, 999-1010. [CrossRef]

77. DeMason, D.A.; Stillman, J.I.; Ellmore, G.S. Acid phosphatase localization in seedling tissues of the palms, Phoenix dactylifera and Washingtonia filifera, and its relevance to controls of germination. Can. J. Bot. 1989, 67, 1103-1110. [CrossRef]

78. Feenstra, A.D.; Alexander, L.E.; Song, Z.; Korte, A.R.; Yandeau-Nelson, M.D.; Nikolau, B.J.; Lee, Y.J. Spatial mapping and profiling of metabolite distributions during germination. Plant. Physiol. 2017, 174, 2532-2548. [CrossRef] [PubMed]

(C) 2020 by the authors. Licensee MDPI, Basel, Switzerland. This article is an open access article distributed under the terms and conditions of the Creative Commons Attribution (CC BY) license (http://creativecommons.org/licenses/by/4.0/). 